ISSN 1392-3196 / e-ISSN 2335-8947

Zemdirbyste-Agriculture, vol. 106, No. 4 (2019), p. 321-328

DOI $10.13080 /$ z-a.2019.106.041

\title{
The introduction of soybean in an organic crop rotation in the Nemoral zone: the impact on subsequent spring wheat productivity
}

\author{
Monika TOLEIKIENE ${ }^{1}$, Caroline BROPHY ${ }^{2}$, Aušra ARLAUSKIENE ${ }^{3}$, Jim RASMUSSEN $^{4}$, \\ Viktorija GECAITE ${ }^{3}, \check{Z ̌ y d r e ̀ ~ K A D Z ̌ I U L I E N E ~}^{1}$
}

${ }^{1}$ Lithuanian Research Centre for Agriculture and Forestry, Institute of Agriculture

Instituto 1, Akademija, Kèdainiai distr., Lithuania

E-mail: monika.toleikiene@lammc.lt

${ }^{2}$ Maynooth University, Department of Mathematics and Statistics

Maynooth, Co Kildare, Ireland

${ }^{3}$ Lithuanian Research Centre for Agriculture and Forestry, Joniškèlis Experimental Station

Karpių 1, Joniškèlis, Pasvalys distr., Lithuania

${ }^{4}$ Aarhus University, Department of Agroecology - Climate and Water

Foulum, Denmark

\begin{abstract}
The sustainability of an organic crop rotation frequently depends on the residual effects of legume pre-crops. However, the contribution of legumes varies considerably depending on their species as well as local soil and climatic conditions. This research aims to compare the pre-crop effects of traditional grain and forage legumes with those of soybean (Glycine $\max$ (L.) Merr.), which is not widespread in Europe latitude $55^{\circ}$ due to climatic constrains, on the productivity of subsequent cereals. A three-year (2016-2018) crop rotation was investigated using four pre-crops: spring barley, spring barley intercropped with red clover, pea and soybean. The effect of pre-crops on grain yield and quality and chemical composition of subsequently grown spring wheat was explored. Nitrogen $(\mathrm{N})$ content in grain and straw, mineral nitrogen $\left(\mathrm{N}_{\min }\right)$ content in the soil were measured, the carbon to nitrogen $(\mathrm{C}: \mathrm{N})$ ratio and net $\mathrm{N}$ balance were calculated. The rotation was repeated twice and the results showed that pea and soybean did not produce sufficient biomass and amount of fixed $\mathrm{N}$ to maintain a stable positive residual effect in both rotation replications. Under favourable conditions, pea derived $66.1 \mathrm{~kg} \mathrm{ha}^{-1} \mathrm{~N}$ and soybean $64.7 \mathrm{~kg} \mathrm{ha}^{-1} \mathrm{~N}$ from the atmosphere, while red clover intercropped with spring barley produced $65.4-82.7 \mathrm{~kg} \mathrm{ha}^{-1} \mathrm{~N}$ yearly. Most of the total $\mathrm{N}\left(\mathrm{N}_{\text {tot }}\right)$ accumulated by pea and soybean plants, $69 \%$ and $80 \%$, respectively, was removed with grain yield, while comparable percentages of $\mathrm{N}(59-68 \%)$ were left by the residues of red clover and spring barley mixture. As a result, the greatest effect on subsequently grown spring wheat was exerted by the mixture of spring barley and red clover (yield increase $354-1414 \mathrm{~kg} \mathrm{ha}^{-1}$ ). Comparing grain legumes, only efficiently nodulated soybean produced a positive $+20.6 \mathrm{~kg} \mathrm{ha}^{-1}$ net $\mathrm{N}$ balance and increased the yield of spring wheat by 920 $\mathrm{kg} \mathrm{ha}^{-1}$. Pea resulted in the negative net $\mathrm{N}$ balance and increased the yield of spring wheat by $534 \mathrm{~kg} \mathrm{ha}^{-1}$. Mineral nitrogen in the soil increased under all legume pre-crops only in the second year of the crop rotation.
\end{abstract}

Key words: nitrogen, pea, pre-crop, red clover.

\section{Introduction}

Biological nitrogen $(\mathrm{N})$ fixation by legumes is an important tool in organic farming, especially in stockless arable organic systems (Migliorini et al., 2014; Watson et al., 2017; Räberg et al., 2018), and has been perceived as a strategy to reduce the use of inorganic fertilizer and to decrease $\mathrm{N}$ import from conventional sources (Foley et al., 2011). Increasing the proportion of legume crops in a rotation, increases the proportion of $\mathrm{N}$ in the global nutrient cycles and also decreases the quantity of $\mathrm{N}$ lost from it (Seufert et al., 2012). At the ecosystem level, the net $\mathrm{N}$ gain due to $\mathrm{N}_{2}$ fixation benefits the subsequent crops and contributes to increased soil $\mathrm{N}$ fertility (Kumar, Goh, 2000; Janušauskaite et al., 2013). Legume diversification increases the quantity, quality and chemical diversity of residues, in such a way that high diversity rotations can sustain soil biological communities and positively affect the soil organic matter (Tiemann et al., 2015).

Many studies have quantified rotational effects, often called pre-crop, break crop or residual effects (Angus et al., 2015; Feiziene at al., 2016; Grant et al., 2016). However, the $\mathrm{N}$ contribution by legumes varies considerably depending on their species as well as local

Please use the following format when citing the article:

Toleikienė M., Brophy C., ArlauskienėA., Rasmussen J., Gecaitė V., KadžiulienėŽ. 2019. The introduction of soybean in an organic crop rotation in the Nemoral zone: the impact on subsequent spring wheat productivity. Zemdirbyste-Agriculture, 106 (4): $321-328$. DOI $10.13080 / \mathrm{z}-\mathrm{a} .2019 .106 .041$ 
soil and climatic conditions (Pandey et al., 2017). The most described legume yield stresses are excess or lack of precipitation (Nielsen, 2011; Cerezini et al., 2016). Insufficient water supply leads to retarded growth with short plant height, stunted flowering and pod set and thus reduced grain yield (Liu et al., 2008). Also, the total $\mathrm{N}$ $\left(\mathrm{N}_{\text {tot }}\right)$ accumulation by individual crop species varies in a wide range between different years and sites (Luce et al., 2015; De Notaris et al., 2019). Under European conditions, grain legume pre-crop effects are variable and increase cereal yields by $500-1600 \mathrm{~kg} \mathrm{ha}^{-1}$. Often, yield benefits of legumes to subsequent crops are the highest under low $\mathrm{N}$ fertilisation, and the $\mathrm{N}$ fertiliser rates be can be reduced by on average $60 \mathrm{~kg} \mathrm{ha}^{-1} \mathrm{~N}$ with no significant yield penalty (Preissel et al., 2015).

In European countries, there is a limitation in use of animal manure from conventional farms in an organic crop rotation (Pandey et al., 2017). In such systems, production of grain legumes offers multiple environmental benefits and can enhance sustainability of European farming, but their production area is declining constantly (Preissel et al., 2015). The decrease in legume cultivation in most of European agriculture remains poorly understood (Iannetta et al., 2016), but legume production in Lithuania is currently increasing. Lithuania is among the leaders in European Union's field pea market with a high increase of pea acreage and production since 2015 (FAOSTAT, 2019, http://www. fao.org/faostat/en/\#data/QC/visualize). It is therefore important to investigate pea in a crop rotation in the local climatic conditions, also to compare it with non-legume pre-crops (spring barley), forage legumes (spring barley + red clover) and non-traditional but high in demand grain legume - soybean (Glycine max (L.) Merr.). Soybean areas in Europe have been limited by climatic constraints until now, but considerable potential for development has emerged (de Visser et al., 2014) thanks to the availability of new superior varieties, developed under cool growing conditions of European Union (Zimmer et al., 2016). However, European soils are free of soybean specific rhizobia (Albareda et al., 2009) and should be inoculated by specific bacteria Bradyrhizobium japonicum (Cerezini et al., 2016).

In organic soybean production, establishment of an effective rhizobial symbiosis is therefore crucial for soybean production and overall soil fertility (Herridge, Rose, 2000; Batista, Dixon, 2019). The formation of root nodules, the process of $\mathrm{N}_{2}$ fixation within nodules and the legume's subsequent reliance upon $\mathrm{N}_{2}$ fixation for growth depend on many variables, such as the presence of effective rhizobial strains, soil acidity $(\mathrm{pH})$, temperature, moisture and concentrations of nitrates (Chalk et al., 2010). The amounts of $\mathrm{N}_{2}$ fixed by legumes are strongly related to legume biomass production and so is the residual effect in a crop rotation (Peoples et al., 2009; Unkovich et al., 2010).

In summary, grain legume pre-crop value is a crucial component of its farm-economic profitability in
European cropping systems, but further experimental research is required to ascertain its magnitude (Preissel et al., 2015). Developing an organic arable farming system, which is self-sufficient in $\mathrm{N}$ supply while maintaining high yields, is very important and also challenging. Little is known about how these different legume crops with different growth requirements and within different crop rotations contribute to the net $\mathrm{N}$ balance in an organic arable farming system with low or no external $\mathrm{N}$ input (Pandey et al., 2017). While pea investigations would give the evidence about its use in dominant crop rotations in cool temperate climate, less is known about how different soil and climatic conditions will affect $\mathrm{N}$ contributions by non-traditional species of legumes such as soybean in these systems.

The objectives of the present study were to: (1) quantify and compare the inputs of fixed $\mathrm{N}$ to rotational $\mathrm{N}$ cycle by soybean, field pea and red clover intercropped with barley, and (2) determine the impact of legume precrops on subsequent spring wheat grain yield and quality and $\mathrm{N}$ uptake.

\section{Materials and methods}

Experimental site and conditions. Field experiments were conducted at Institute of Agriculture $\left(55^{\circ} 23^{\prime} 49^{\prime \prime} \mathrm{N} 23^{\circ} 51^{\prime} 40^{\prime \prime} \mathrm{E}\right)$, Lithuanian Research Centre for Agriculture and Forestry. The experimental site is situated in a temperate climatic zone which can also be referred to as Nemoral environmental zone, where the growing season lasts for 169-202 days. The experimental site is located above the northern boundary of typical soybean (Glycine $\max$ (L.) Merr.) distribution $-55^{\circ} 24^{\prime}$ $\mathrm{N}$, with reference to Ray et al. (2012), who defined typical soybean cultivation area in Europe to occur at up to the $49^{\circ} \mathrm{N}$ latitude. At the experimental site, the sum of active temperatures $\left(\Sigma \mathrm{T}>10^{\circ} \mathrm{C}\right)$ is $2100-2200^{\circ} \mathrm{C}$, the annual precipitation totals $500-600 \mathrm{~mm}$ and the mean annual air temperature is $6.5^{\circ} \mathrm{C}$. In 2016 and 2018, the temperature of the growing season was higher than the long-term average of 1980-2016. In 2016 and 2017, the spring was relatively dry, but summer unusually wet. In 2018, the summer was drier compared with the long-term average of the 1928-2016 period (Table 1).

The soil of the experimental site was a loamy Endocalcaric Epigleyic Cambisol (Drainic, Loamic) (WRB, 2014). Characteristics of the soil arable layer varied between the experimental years 2016 and 2017 . Soil in the spring of 2016: acidity $(\mathrm{pH})-7.2 \pm 0.5$, humus - 2.3\%, $\mathrm{P}_{2} \mathrm{O}_{5}-93 \mathrm{mg} \mathrm{kg}{ }^{-1}, \mathrm{~K}_{2} \mathrm{O}-156 \mathrm{mg} \mathrm{kg}^{-1}$, mineral nitrogen $\left(\mathrm{N}^{5}\right)-7.86 \mathrm{mg} \mathrm{kg}^{-1}$; in the spring of 2017: $\mathrm{pH}-7.0 \pm 0.5$, humus $-2.7 \%, \mathrm{P}_{2} \mathrm{O}_{5}-84 \mathrm{mg} \mathrm{kg}^{-1}$, $\mathrm{K}_{2} \mathrm{O}-150 \mathrm{mg} \mathrm{kg}^{-1}, \mathrm{~N}_{\text {in }}-11.6 \mathrm{mg} \mathrm{kg}^{-2}$. Meteorological and soil chemical conditions show that the year 2017 was more favourable for pre-crops to grow than 2016 because of the two reasons. Firstly, in the spring of 2016 the water content in soil was lower because of the dry 2015 , but in the spring of 2017 , even with lower amount

Table 1. Monthly air temperature and precipitation during the growing seasons in 2016-2019

\begin{tabular}{|c|c|c|c|c|c|c|c|c|}
\hline \multirow{2}{*}{ Month } & \multicolumn{4}{|c|}{ Average air temperature ${ }^{\circ} \mathrm{C}$} & \multicolumn{4}{|c|}{ Sum of precipitation $\mathrm{mm}$} \\
\hline & $\mathrm{AVG}$ & 2016 & 2017 & 2018 & AVG & 2016 & 2017 & 2018 \\
\hline January & -4.7 & -8.0 & -3.2 & -1.6 & 31.1 & 35.9 & 14.2 & 55.5 \\
\hline February & -4.4 & 1.5 & -1.6 & -6.1 & 25.5 & 78.5 & 25.1 & 16.2 \\
\hline March & -0.7 & 1.9 & 3.5 & -1.9 & 28.1 & 37.1 & 38.9 & 17.3 \\
\hline April & 5.8 & 7.1 & 5.6 & 9.9 & 36.9 & 59.5 & 48.2 & 52.1 \\
\hline May & 12.3 & 15.0 & 12.8 & 16.9 & 52.1 & 27.3 & 3.4 & 40.2 \\
\hline June & 15.7 & 17.5 & 15.4 & 17.5 & 62.3 & 57.4 & 72.1 & 34.1 \\
\hline July & 17.7 & 18.6 & 16.7 & 20.5 & 75.5 & 128.2 & 153.8 & 83.3 \\
\hline August & 16.7 & 17.1 & 17.3 & 19.5 & 74.2 & 109.2 & 53.2 & 37.0 \\
\hline September & 12.1 & 14.0 & 13.3 & 15.0 & 51.3 & 8.7 & 123.1 & 19.1 \\
\hline October & 6.8 & 5.4 & 7.4 & 8.3 & 49.1 & 87.9 & 89.3 & 32.8 \\
\hline November & 1.9 & 1.3 & 4.0 & 2.9 & 45.0 & 78.4 & 51.0 & 13.1 \\
\hline December & -2.3 & 0.9 & 1.0 & -1.1 & 37.6 & 41.1 & 64.0 & 60.8 \\
\hline
\end{tabular}

AVG - long-term average of the 1928-2016 period 
of precipitation, the soil had extra moisture because of the wet 2016. Secondly, the $\mathrm{N}_{\min }$ after a dry year of 2015 was low in the spring of 2016, but in the spring of 2017 it was higher because of the dry 2016.

Experimental design and treatments. The experiment was repeated twice in three-year crop rotations of legume and cereal crops in 2016-2017 and 2017-2018 and was referred to as rotation A and B, respectively (Table 2). Four pre-crop species were used as treatments in the first year of the crop rotation: spring barley (SB), spring barley with red clover $(\mathrm{SB}+\mathrm{RC})$ intercropping, pea and soybean.

Table 2. Experimental design of the crop rotation replicated in time

\begin{tabular}{llc}
\hline $\begin{array}{l}1^{\text {st }} \text { crop rotation } \\
\text { replication } \\
\text { (rotation A) }\end{array}$ & 2016 & 2017 \\
\hline $\begin{array}{l}2^{\text {nd }} \text { crop rotation } \\
\text { replication } \\
\text { (rotation B) }\end{array}$ & \multicolumn{1}{c}{2017} & 2018 \\
& \multicolumn{1}{c}{ 1) spring barley, } \\
$\begin{array}{l}\text { Treatments } \\
\text { and crops: }\end{array}$ & $\begin{array}{l}\text { 2) spring barley }+ \\
\text { red clover, }\end{array}$ & spring wheat \\
& $\begin{array}{l}\text { 3) pea, } \\
\text { 4) soybean }\end{array}$ & \\
\hline
\end{tabular}

The experiment was laid out in a randomized complete block design with four replications. Each plot was $3.0 \mathrm{~m}$ wide and $10.0 \mathrm{~m}$ long. All crops were sown with a disk drill at a $3 \mathrm{~cm}$ depth. Soybean cultivar 'Merlin', belonging to an early 000-maturity group, was sown on May 20 in 2016 and May 15 in 2017 at a seed rate of $120 \mathrm{~kg} \mathrm{ha}^{-1}$, was harvested on October 31 in 2016 and October 15 in 2017. Soybean seeds were inoculated with a Bradyrhizobium japonicum strain SEMIA5079 (=CPAC 15), containing $1.2 \times 10^{9}$ colony forming units (CFU) $\mathrm{mL}^{-1}$. The dose of inoculant was calculated to deliver $1.2 \times 10^{6}$ cells per seed. The pea cultivar 'Respect' was sown on May 3 in 2016 and April 27 in 2017 at a seed rate of $300 \mathrm{~kg} \mathrm{ha}^{-1}$, was harvested on August 3 in 2016 and August 7 in 2017. The spring barley cultivar 'Noja DS' was sown on May 5 in 2016 and April 21 in 2017 at a seed rate of $220 \mathrm{~kg} \mathrm{ha}^{-1}$, harvested on August 5 in 2016 and August 14 in 2017. The red clover cultivar 'Arimaičiai' was intercropped in spring barley on May 5 in 2016 and May 7 in 2017 at a seed rate of $10 \mathrm{~kg} \mathrm{ha}^{-1}$, was cut twice per year on August 5 and October 5 in 2016 and on August 14 and October 23 in 2017. The spring wheat cultivar 'Granary' was sown on April 23 in 2016 and April 28 in 2017 at a seed rate of $230 \mathrm{~kg} \mathrm{ha}^{-1}$, was harvested on August 31 in 2016 and August 31 in 2017.
The residues of legume plants were incorporated into the $0-10 \mathrm{~cm}$ soil layer by a disk cultivator and later in the autumn were ploughed down at the $25 \mathrm{~cm}$ depth. The first cut of red clover in the $2^{\text {nd }}$ treatment was taken after spring barley harvesting, and the second cut was taken late in the autumn. The plots were harrowed in the spring before sowing of spring wheat as a subsequent crop. The experimental site was managed according to the rules of organic farming.

Data collection and analysis. Grain yield was measured while harvesting $3 \times 10 \mathrm{~m}$ plots. The following grain quality traits were measured: 1000 kernel weight (TKW), content of protein, fat, moisture, glycemic index and grain density using a grain analyser Infratec 1241 (Foss, Denmark). Crop and straw yield was determined in $4 \times 0.25 \mathrm{~m}^{2}$ sampling areas in each plot. Soil samples for $\mathrm{N}_{\min }$ determination were taken in the spring, before sowing, from the $0-30$ and $30-60 \mathrm{~cm}$ depths. The concentration of humus in the soil was determined by the Diameter method by an automatic analyser Vario EL (Elementar, Germany), N ( $\left.\mathrm{g} \mathrm{kg}^{-1}\right)$ by the Kjeldahl method using a final photometric determination (UV/ Vis Cary 50 Conc), $\mathrm{P}\left(\mathrm{g} \mathrm{kg}^{-1}\right)$ by the final photometric determination (UV/Vis Cary 50 Conc) and $\mathrm{K}\left(\mathrm{g} \mathrm{kg}^{-1}\right)$ by the atomic absorption method (atomic absorption spectrophotometer ANALYST 200, UK). Nitrogen fixation $\left(\mathrm{N}_{\mathrm{fix}}\right)$ from the atmosphere was calculated using difference method (Herridge, Danso, 1995), where the main equation includes $\mathrm{N}$ contents of a non- $\mathrm{N}_{2}$-fixing plant $\left(\mathrm{N}_{\text {nonfix }}\right)$ grown in the same soil (plot) as the $\mathrm{N}_{2}$ fixing crop monoculture or mixture $\left(\mathrm{N}_{\mathrm{leg} / \text { mix }}\right) / \mathrm{N}_{\mathrm{fix}}=\mathrm{N}_{\mathrm{leg}}^{2}$ $-\mathrm{N}_{\text {nonfix }}$. Total plant $\mathrm{N}$ was calculated by summing up $\mathrm{N}$ m content of grain and residues / straw. Net $\mathrm{N}$ balance was calculated as follows: of residues net $\mathrm{N}$ balance $=$ total plant $\mathrm{N}-\mathrm{N}$ fixed $+\mathrm{N}$ Statistical analysis was performed using analysis of variance $(A N O V A)$ on the statistical program SAS Enterprise, version 9.4 (SAS Institute Inc., USA). Homogeneity and normality were verified using Bartlett's test. The interaction between years was tested. Means for significant effects were separated using Tukey multiple range tests at the $5 \%$ probability level $(P<0.05)$.

\section{Results}

Pre-crop value. Four species were cultivated as pre-crops in the organic crop rotation in 2016 and 2017 which are below referred to as rotation A and $\mathrm{B}$, respectively. The value of pre-crops, estimated as accumulated yield of grain and straw, differed between the experimental years (Table 3 ).

Table 3. The dry matter (DM) yield of grain and straw of the four pre-crops in the first year of the crop rotation

\begin{tabular}{|c|c|c|c|c|c|}
\hline \multirow{3}{*}{ Treatment } & & \multicolumn{2}{|c|}{ Rotation A } & \multicolumn{2}{|c|}{ Rotation B } \\
\hline & grain yield & straw yield & grain yield & straw yield & \\
\hline & \multicolumn{3}{|c|}{$\mathrm{kg} \mathrm{ha}^{-1} \mathrm{DM}$} & & \\
\hline \multirow{2}{*}{ Spring barley } & & $1346 \mathrm{a}$ & $1782 \mathrm{cb}$ & $2395 \mathrm{~b}$ & $1728 \mathrm{bc}$ \\
\hline & spring barley & $1197 \mathrm{a}$ & $1194 \mathrm{c}$ & $2137 \mathrm{~b}$ & $1149 \mathrm{~d}$ \\
\hline \multirow[t]{2}{*}{ Spring barley + red clover } & red clover ( $1^{\text {st }}$ cut $)$ & - & $1418 \mathrm{c}$ & - & $1133 \mathrm{~d}$ \\
\hline & red clover $\left(2^{\text {nd }}\right.$ cut $)$ & - & $2818 \mathrm{a}$ & - & $2051 \mathrm{~b}$ \\
\hline Pea & & $1150 \mathrm{a}$ & $1350 \mathrm{c}$ & $3245 \mathrm{a}$ & $2647 \mathrm{a}$ \\
\hline Soybean & & $1622 \mathrm{a}$ & $2212 \mathrm{~b}$ & $830 \mathrm{c}$ & $1226 \mathrm{~cd}$ \\
\hline
\end{tabular}

Note. Means followed by the same letters in the same column do not differ from one another $(p \leq 0.05)$ according to Tukey test.

Significant interaction $(p<0.001)$ regarding grain and straw yield was found between years and treatments (Fig. 1). While field pea demonstrated the same trend as cereals, soybean failed to benefit from better growing conditions of 2017. The main reason was ineffective symbiosis of soybean with the applied B. japonicum bacteria in 2017. As a result, soybean grain yield decreased from 1622 to $830 \mathrm{~kg} \mathrm{ha}^{-1} \mathrm{DM}$ and the yield of straw from 2212 to $1226 \mathrm{~kg} \mathrm{ha}^{-1} \mathrm{DM}$ in 2016 and 2017, respectively (Table 3 ). Significantly similar $(p>0.05)$ amounts $\left(1150-1622 \mathrm{~kg} \mathrm{DM} \mathrm{ha}^{-1}\right)$ of grain yield were accumulated by the four pre-crops in rotation A. Significantly higher amounts of straw were accumulated by soybean $\left(2212 \mathrm{~kg} \mathrm{ka}^{-1}\right)$ and red clover $\left(4236 \mathrm{~kg} \mathrm{ka}^{-1}\right)$ intercropped in spring barley. In rotation $\mathrm{B}$, field pea produced 2.8 times more DM yield of grain than field 


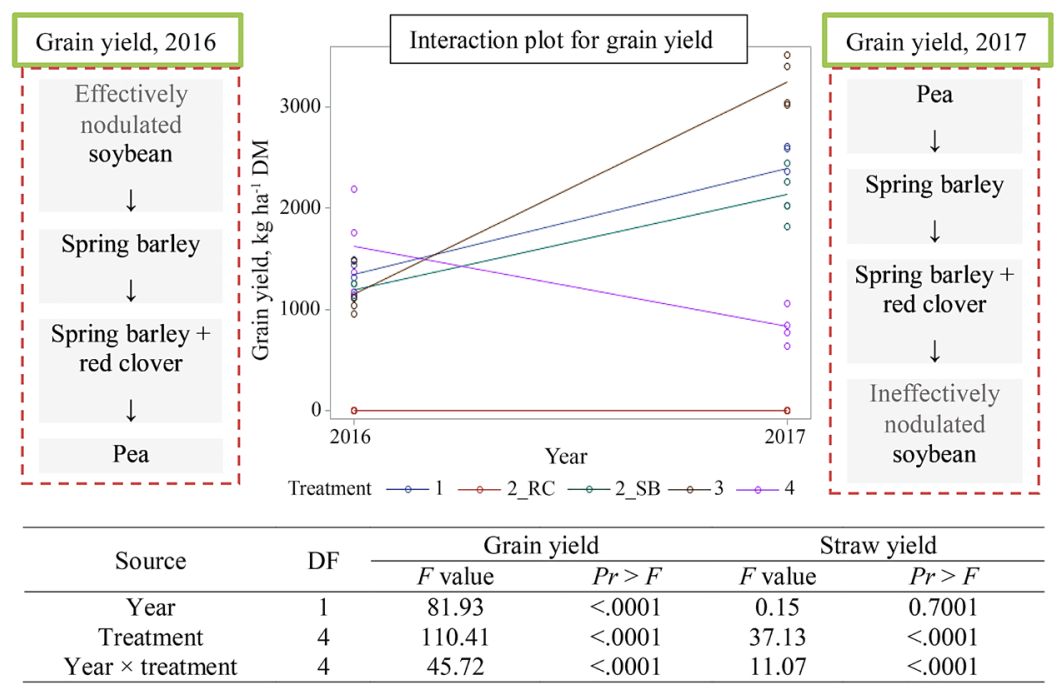

RC - red clover, SB - spring barley; DF - degree of freedom, $F$ - value according to Fisher test, $P r$ - level of probability

Figure 1. The main effects and treatment and year interaction in relation to the dry matter (DM) yield $\left(\mathrm{kg} \mathrm{ha}^{-1}\right)$ of grain and straw of the four pre-crop species

pea in rotation A, which was further significantly higher than that of the other three pre-crops in rotation $\mathrm{B}$.

The $\mathrm{N}$ accumulation in grain was the highest $(<0.01)$ for soybean plants $(5.02-5.06 \% \mathrm{~N})$ in both $\mathrm{A}$ and $\mathrm{B}$ rotations and the lowest for spring barley $(1.61-1.76 \%$ N) (Table 4). Higher variation between years was found for $\mathrm{N}$ content in straw than in grains, depending on the efficiency of $\mathrm{N}$ fixation, $0.56-1.67 \% \mathrm{DM}$ for soybean and $2.18-3.13 \%$ DM for red clover. Biomass of red clover as a forage legume was distinguished by the narrowest carbon to nitrogen $(\mathrm{C}: \mathrm{N})$ ratio $(14.8-22.0)$. The $\mathrm{C}: \mathrm{N}$ in the straw of grain legumes, pea and soybean varied substantially between the two years. Under unfavourable growing conditions, the $\mathrm{C}: \mathrm{N}$ of both pea and soybean straw was comparable to that of spring barley straw. Conversely, under more favourable conditions the $\mathrm{C}: \mathrm{N}$ in pea and soybean straw was 1.5-2.6-fold higher.

Table 4. Nitrogen (N) and carbon (C) accumulated in the grains and straw of the pre-crops in the first year of the crop rotations, $\%$ dry matter

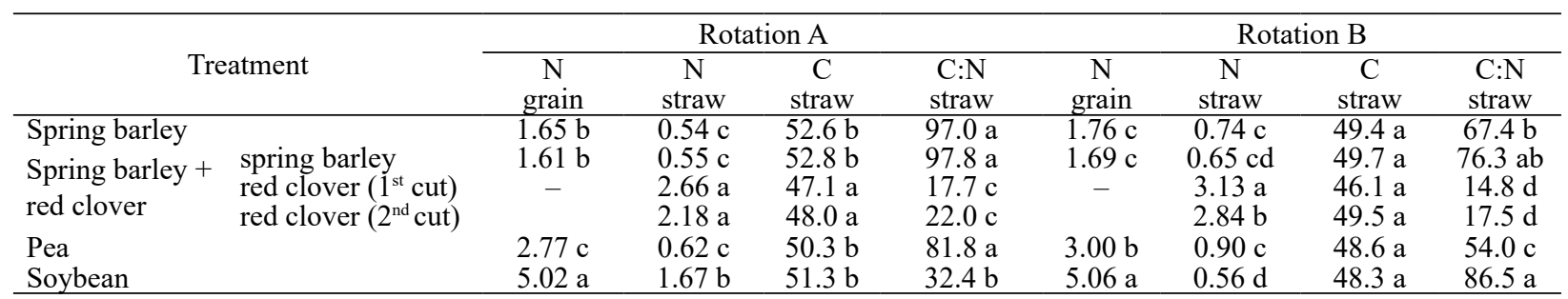

Note. Means followed by the same letters in the same column do not differ from one another $(p \leq 0.05)$ according to Tukey test.

The total plant $\mathrm{N}$ yield was the highest in the pre-crop of spring barley intercropped with red clover (119.6-137.6 $\left.\mathrm{kg} \mathrm{ha}^{-1}\right)$, but significantly similar amount of $\mathrm{N}$ was accumulated by soybean in rotation $\mathrm{A}\left(118.9 \mathrm{~kg} \mathrm{ha}^{-1}\right)$ and pea in rotation B (121.1 kg ha $\left.{ }^{-1}\right)$ (Fig. 2). Most of the total $\mathrm{N}$ accumulated by pea and soybean plants, $69 \%$ and $80 \%$ respectively, was removed with grain yield, while comparable percentages of $\mathrm{N}(59-68 \%)$ were left by the residues of red clover and spring barley mixture. This determined the highest positive net $\mathrm{N}$ balance $(+33.3$ and $\left.+54.0 \mathrm{~kg} \mathrm{ha}^{-1}\right)$ in spring barley and red clover precrop. Grain legumes investing high levels of $\mathrm{N}$ in seed production had negative net $\mathrm{N}$ balance, except for effectively nodulated soybean in rotation A.

Pre-crop effect on subsequent crop. Spring wheat, cultivated in subsequent year after four precrops, produced significantly different yields of grain, the highest being after spring barley and red clover precrops in both $\mathrm{A}$ and $\mathrm{B}$ rotations (Table 5). It produced $354-1414 \mathrm{~kg} \mathrm{ha}^{-1}$ higher yield than sole spring barley.

Table 5. Spring wheat aboveground biomass, yield and grain traits

\begin{tabular}{|c|c|c|c|c|c|c|c|}
\hline Treatment & $\begin{array}{c}\text { Grain yield } \\
\mathrm{kg} \mathrm{ha}^{-1}\end{array}$ & $\begin{array}{c}\text { Biomass } \\
\mathrm{g} \mathrm{m}^{-2}\end{array}$ & $\begin{array}{c}\text { Glycemic } \\
\text { index }\end{array}$ & $\begin{array}{c}\text { Protein } \\
\%\end{array}$ & $\begin{array}{c}\text { Starch } \\
\%\end{array}$ & $\begin{array}{c}\text { TKW } \\
\mathrm{g}\end{array}$ & $\begin{array}{c}\text { Density } \\
\mathrm{kg} \mathrm{h}^{-1}\end{array}$ \\
\hline \multicolumn{8}{|c|}{ Rotation A } \\
\hline Spring barley & $1243 \mathrm{c}$ & $364 \mathrm{~b}$ & $18.7 \mathrm{~b}$ & $10.7 \mathrm{~b}$ & $68.3 \mathrm{a}$ & $29.7 \mathrm{~b}$ & $65.6 \mathrm{~b}$ \\
\hline Spring barley + red clover & $2657 \mathrm{a}$ & $593 \mathrm{a}$ & $20.1 \mathrm{a}$ & $11.7 \mathrm{a}$ & $67.2 \mathrm{~b}$ & $32.9 \mathrm{a}$ & $67.6 \mathrm{ab}$ \\
\hline Pea & $1777 \mathrm{bc}$ & $455 \mathrm{ab}$ & $19.4 \mathrm{a}$ & $11.2 \mathrm{a}$ & $67.7 \mathrm{ab}$ & $32.2 \mathrm{a}$ & $67.7 \mathrm{ab}$ \\
\hline Soybean & $2163 \mathrm{ab}$ & $495 \mathrm{ab}$ & $19.7 \mathrm{a}$ & $11.2 \mathrm{a}$ & $67.8 \mathrm{ab}$ & $33.4 \mathrm{a}$ & $69.2 \mathrm{a}$ \\
\hline \multicolumn{8}{|c|}{ Rotation B } \\
\hline Spring barley & $1932 \mathrm{~b}$ & $494 \mathrm{ab}$ & $16.9 \mathrm{~b}$ & $9.8 \mathrm{~b}$ & $69.1 \mathrm{a}$ & $43.9 \mathrm{a}$ & $81.3 \mathrm{ab}$ \\
\hline Spring barley + red clover & $2286 a$ & 558 a & $19.7 \mathrm{a}$ & $10.9 \mathrm{a}$ & $68.4 \mathrm{a}$ & $43.8 \mathrm{a}$ & $82.3 \mathrm{a}$ \\
\hline Pea & $1984 \mathrm{~b}$ & $499 \mathrm{ab}$ & $16.9 \mathrm{~b}$ & $9.9 \mathrm{~b}$ & $68.9 \mathrm{a}$ & $43.8 \mathrm{a}$ & $81.0 \mathrm{~b}$ \\
\hline Soybean & $1895 \mathrm{~b}$ & $458 \mathrm{~b}$ & $16.8 \mathrm{~b}$ & $9.9 \mathrm{~b}$ & $68.9 \mathrm{a}$ & $43.2 \mathrm{a}$ & $81.3 \mathrm{ab}$ \\
\hline
\end{tabular}

Note. TKW - 1000 kernel weight; means followed by the same letters in the same column do not differ from one another $(p \leq 0.05)$ according to Tukey test. 


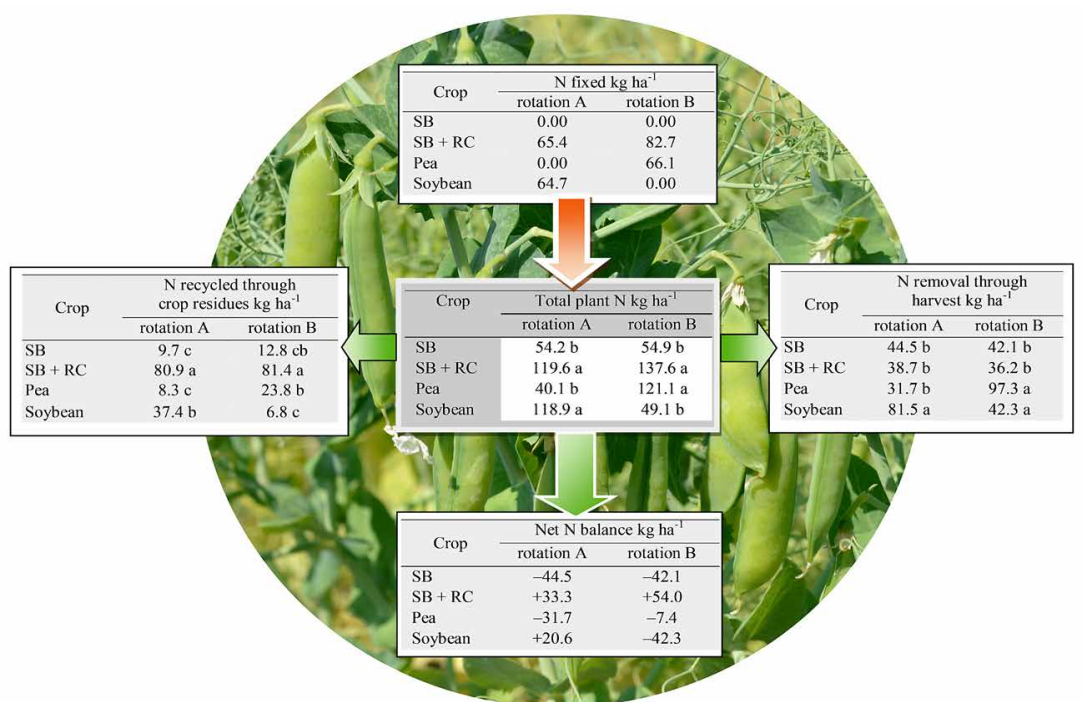

Note. SB - spring barley, RC - red clover; means followed by the same letters in the same column do not differ from one another $(p \leq 0.05)$ according to Tukey test.

Figure 2. Allocation of the total plant nitrogen $(\mathrm{N})$ to shoots and grains, $\mathrm{N}$ fixed and net $\mathrm{N}$ balance in the first year of the crop rotation

Grain legumes, pea and soybean, resulted in significantly higher grain yield of spring wheat by 534 and $920 \mathrm{~kg} \mathrm{ha}^{-1}$ only in rotation A. In addition, in rotation A, all legume pre-crops gave significant increase in protein content (by 5-9\%), glycemic index (by 4-7\%) and 1000 kernel weight (by $8-10 \%$ ) of spring wheat. However, in rotation $\mathrm{B}$, only red clover intercropped in spring wheat could significantly enhance protein content and, consequently, glycemic index of spring wheat.

In order to evaluate aftereffect of pre-crop legumes on subsequent winter wheat, which was grown after spring wheat in the third year of the crop rotation, the main characteristics of spring wheat residues were assessed. The content of $\mathrm{N}$ and $\mathrm{C}$ and $\mathrm{C}: \mathrm{N}$ of straw did not differ significantly among the treatments in both rotations. However, straw weight was significantly higher for spring wheat cultivated after spring barley intercropped with red clover, as well as after soybean pre-crop in rotation A, compared with sole spring barley (Table 6). In rotation B, no significant differences were detected.

Mineral $N\left(N_{m i p}\right)$ in the rotation. The $\mathrm{N}_{\text {. }}$ content in the soil varied from 3 to $14 \mathrm{~g} \mathrm{~kg}^{-1} \mathrm{~N} \mathrm{DM}$, showing time related effect of legume pre-crops through the three-year long crop rotation (Fig. 3).

Table 6. Yield, carbon (C) and nitrogen (N) content, $\mathrm{C}$ to $\mathrm{N}$ ratio of straw of spring wheat

\begin{tabular}{|c|c|c|c|c|c|c|c|c|}
\hline \multirow[b]{2}{*}{ Treatment } & \multicolumn{4}{|c|}{ Rotation A } & \multicolumn{4}{|c|}{ Rotation B } \\
\hline & $\begin{array}{c}\text { straw yield } \\
\mathrm{g} \mathrm{m}^{-2}\end{array}$ & $\begin{array}{c}\mathrm{N} \\
\% \mathrm{DM}\end{array}$ & $\begin{array}{c}\mathrm{C} \\
\% \mathrm{DM}\end{array}$ & $\mathrm{C}: \mathrm{N}$ & $\begin{array}{c}\text { straw yield } \\
\mathrm{g} \mathrm{m}^{-2}\end{array}$ & $\begin{array}{c}\mathrm{N} \\
\% \mathrm{DM}\end{array}$ & $\begin{array}{c}\mathrm{C} \\
\% \mathrm{DM}\end{array}$ & $\mathrm{C}: \mathrm{N}$ \\
\hline Spring barley & $179 \mathrm{~b}$ & $0.447 \mathrm{a}$ & $50.3 \mathrm{a}$ & $113 \mathrm{a}$ & $301 \mathrm{ab}$ & $0.328 \mathrm{a}$ & $52.6 \mathrm{a}$ & $163 \mathrm{a}$ \\
\hline Spring barley + red clover & $270 \mathrm{a}$ & $0.488 \mathrm{a}$ & $50.6 \mathrm{a}$ & $105 \mathrm{a}$ & $329 \mathrm{a}$ & $0.410 \mathrm{a}$ & $51.4 \mathrm{a}$ & $127 \mathrm{a}$ \\
\hline Pea & $223 \mathrm{ab}$ & $0.491 \mathrm{a}$ & $51.2 \mathrm{a}$ & $106 \mathrm{a}$ & $301 \mathrm{ab}$ & $0.320 \mathrm{a}$ & $51.9 \mathrm{a}$ & $166 \mathrm{a}$ \\
\hline Soybean & $243 \mathrm{a}$ & $0.442 \mathrm{a}$ & $49.9 \mathrm{a}$ & $113 \mathrm{a}$ & $268 \mathrm{~b}$ & $0.321 \mathrm{a}$ & $51.1 \mathrm{a}$ & $160 \mathrm{a}$ \\
\hline
\end{tabular}

Note. DM - dry matter; means followed by the same letters in the same column do not differ from one another $(p \leq 0.05)$ according to Tukey test.
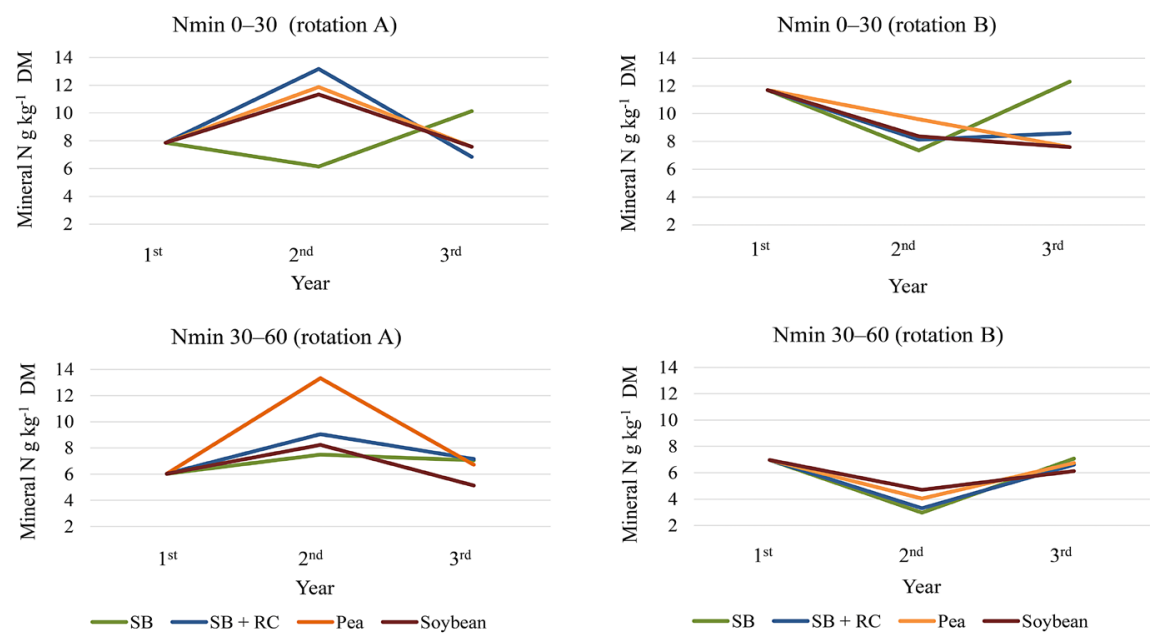

$\mathrm{DM}$ - dry matter; SB - spring barley, $\mathrm{RC}$ - red clover

Figure 3. Mineral nitrogen $(\mathrm{N})$ content in the soil, measured in the spring in crop rotations A and B at $0-30$ and $30-60 \mathrm{~cm}$ depths 
In the spring of 2017 , which was the second year in crop rotation A and first year in crop rotation B, the mineral $\mathrm{N}$ was higher in the deeper $(30-60 \mathrm{~cm})$ soil layer due to high precipitation in the previous year and high content of moisture in the soil, which favoured $\mathrm{N}$ mineralisation in the soil. In the soil depth of $0-30 \mathrm{~cm}$, the increase of $\mathrm{N}_{\min }$ was observed in the second year of the rotation after all legume pre-crops. However, this effect was not apparent in the spring of the third year, when the control treatment with spring barley showed higher amounts of $\mathrm{N}_{\min }$ compared with legumes in both rotations. The decrease of mineral $\mathrm{N}$ in the second year of the rotation and increase in the third year after spring barley pre-crop could be explained by a high $\mathrm{C}: \mathrm{N}$ of the residues. A similar time related trend was noticed in the deeper 30-60 cm soil layer, and a substantial increase of $\mathrm{N}_{\min }$ in the second year was observed for all legumes, especially for pea pre-crop.

\section{Discussion}

Introduction of soybean in the cropping system. In order to optimize management of pests, weeds and diseases and to exploit nutrient availability, crop rotation should incorporate species with different life cycles, growth habits, root architectures and pest spectra (Reckling et al., 2016). Legume incorporation into a rotation could benefit as a break-crop; however, the domination of one legume species does not provide all spectrum of possible benefits. Pea is the most widely grown grain legume in Europe (FAO, http://www.fao. org/faostat/en/\#data/QC/visualize); therefore, soybean introduction in European Union's cropping systems would beneficially impact the environment of the agroecosystem and also would satisfy the socio-economic needs (Nemecek et al., 2008). Our study showed that in a less favourable year with lower mineral $\mathrm{N}$ in the soil, the effectively nodulated soybean can produce a yield of $1622 \mathrm{~kg} \mathrm{ha}^{-1}$, which is higher than that of field pea and spring wheat in the organic farming system. Similar cultivars grown on commercial farms in Sweden had a reported yield of 1500-2400 kg ha-1 (Fogelberg, Fogelberg, 2013). Average soybean yield in organically managed trials in Germany was reported as $1634 \mathrm{~kg}$ $\mathrm{ha}^{-1}$ in the 2012-2013 seasons (Zimmer et al., 2016). In Poland, average soybean yield in 2015 was $1600 \mathrm{~kg}$ ha $^{-1}$ (Wenda-Piesik, Kazek, 2016). Average seed yield worldwide is $2300 \mathrm{~kg} \mathrm{ha}^{-1}$ (Bujak, Frant, 2009). All these data confirm the feasibility of soybean cultivation in a cool temperate climate of the Nemoral zone.

Biological $\mathrm{N}$ fixation varies in relation to the ability of legume species to fix $\mathrm{N}$ in different environmental conditions (Peoples et al., 2009). Across varying pedoclimatic regions of Europe it was shown that biological $\mathrm{N}$ fixation for different legume species ranges from 32 to $115 \mathrm{~kg} \mathrm{ha}^{-1}$ annually (Iannetta et al., 2016). Our results show that the allocation of biologically fixed $\mathrm{N}$ in straw differed between forage and grain legumes. Forage as opposed to grain crops in this range maintain high outputs of biomass and $N_{\text {tot }}$ (Iannetta et al., 2016). In Baltic region, clover was shown to accumulate up to 6.4 $14.9 \mathrm{t} \mathrm{ha}^{-1} \mathrm{DM}$ yield biomass and up to $118-327 \mathrm{~kg} \mathrm{ha}^{-1}$ of $\mathrm{N}$ (Ingver et al., 2019). Forage legumes use $\mathrm{N}$ to produce dry shoot matter more efficiently than grain legumes, whereas accumulation of $\mathrm{N}$ in grains is greater for grain legumes (Iannetta et al., 2016). Therefore, the residual effect is reduced when higher $\mathrm{N}$ amount is lost through harvest for grain legumes (Espinoza et al., 2012). Our data show that $69 \%$ and $80 \%$ of $N$ was accumulated in harvest and removed from the ecosystem in the case of soybean and pea, while as much as $59-68 \%$ of $\mathrm{N}$ was left in the soil by the residues of red clover and spring barley mixture.

By comparing species by species, it was demonstrated that clover has higher $\mathrm{N}$ fixation potential than pea. The proportion of $\mathrm{N}_{2}$ derived from the atmosphere $(\%)$ is also significantly higher for white clover $(90 \%)$ than pea $(69 \%)$ (Kumar, Goh, 2000). Pandey at al. (2017) showed that $\mathrm{N}_{2}$ derived from the atmosphere in the aboveground biomass of red and white clover, grown in mixtures can be close to $100 \%$, whereas derived $\mathrm{N}$ of grain legumes ranged between $61 \%$ and $95 \%$ in Denmark (Pandey et al., 2017). Unkovich and Pate (2000) suggest ranking principal crop legumes according to the quantities of $\mathrm{N}_{2}$ fixed in the following descending order: soybean, lupin, field pea, faba bean, common bean, lentil and chickpea. Under European conditions, field pea was determined to gain $75 \%$ of total crop N, amounting to $150 \mathrm{~kg}$ shoot $\mathrm{N}$ ha, through $\mathrm{N}_{2}$ fixation (Jensen, 1996). In other regions, soybean was reported to have higher effect than pea. Rochester et al. (2001) showed that soybean can fix $453-488 \mathrm{~kg} \mathrm{ha}^{-1} \mathrm{~N}$ per year and contribute $155-280 \mathrm{~kg} \mathrm{ha}^{-1}$ fixed $\mathrm{N}$ to the soil after seed harvest. However, soybean pre-crop value in Europe latitude up to $55^{\circ}$ has not been widely investigated before, and there is a lack of evidence of soybean benefits, particularly advantages over pea in an organic cropping system. Our data show that effectively nodulated soybean can fix similar amounts of $\mathrm{N}$ as pea crop in a favourable year, but the net $\mathrm{N}$ balance is higher when growing soybean and also the impact on subsequent crop is higher than that of pea, which showed negative $\mathrm{N}$ balance in both years.

Nevertheless the pea with negative $\mathrm{N}$ balance managed to improve the yield of subsequent plant by $534 \mathrm{~kg} \mathrm{ha}^{-1}$ compared with spring barley. This could be explained by a range of other benefits of legumes not only through biological $\mathrm{N}$ fixation and enhanced soil $\mathrm{N}$ status (Iannetta et al., 2016). Some other factors are influencing yield positively, implying a cascade effect on other soil and system processes (Ehrmann, Ritz, 2014). This pre-crop benefit of grain legumes can lead to yield increases of up to $1600 \mathrm{~kg} \mathrm{ha}^{-1}$ in subsequent cereals (Preissel et al., 2015).

The influence of soybean on spring wheat productivity. The $\mathrm{N}$ contribution of a legume to subsequent crops is difficult to predict and is dependent on the specific legume, since legume species vary in their ability to biologically fix $N_{2}$ (Peoples et al., 2009). Moreover, the $\mathrm{N}$ contribution of legumes may vary over the years and sites due to variations in environmental conditions and soil properties, which affect the degree of $\mathrm{N}_{2}$ fixation, legume grain yields and the quantity and quality of crop residues (Luce et al., 2015). This is consistent with our own study which assessed the precrop benefits of grain legumes at two replicates of crop rotation in time. It was revealed that in unfavourable conditions when the rate of $\mathrm{N}_{2}$ fixation is low the effect of legumes does not differ from that of non-legume precrops. Also the effect of grain legume pre-crop was more apparent when the productivity of all crop rotation was low because of the environmental conditions, otherwise, in better conditions, this effect did not differ significantly. However, the positive effect of forage legume pre-crop (red clover + spring barley) was more consistent due to higher stability in agroecosystems and lower sensitivity to local climatic variability (Stoddard, 2013).

Studies have shown that conventional forage and grain legumes can increase the productivity of subsequent crops (Šrānaite et al., 2013; Feiziene et al., 2016). Since soybean is not a traditional crop in midNorthern part of Europe, its residual effect is difficult to predict. Inadequate crop management technologies and lack of experience have been identified as constraints for soybean expansion in this region. Improving yield, yield stability, quality and biotic stress resistance are the main aims for soybean introduction in a new region (Albareda et al., 2009). For optimal $\mathrm{N}$ fixation, accumulation and production in an organic ecosystem, inoculation is an advisable agricultural practice when there are no specific rhizobia in the soil (Catroux et al., 2001). This is a common situation in most European soils. However, there is a paucity of knowledge about the efficiency of specific Rhizobia strains for soybean under environmental 
conditions of Baltic-Nordic region in Europe. It is only known that $\mathrm{N}$, derived from the atmosphere and total $\mathrm{N}_{2}$ fixation of soybean vary significantly due to the variation of environmental conditions (Peoples et al., 1995), which highly impacts the nodulation, grain yield and residual effects (Deaker et al., 2004). In agreement, our results demonstrated that effectively nodulated soybean produced $1622 \mathrm{~kg} \mathrm{ha}^{-1}$ grain yield and promoted significant residual effect on subsequent crop, while ineffectively nodulated soybean produced $830 \mathrm{~kg} \mathrm{ha}^{-1}$ grain yield with no significant effect on subsequent crop.

\section{Conclusions}

1. The effect of grain legume pre-crops, soybean and pea, was not stable due to the varying weather conditions. Only in favourable conditions pea derived $66.1 \mathrm{~kg} \mathrm{ha}^{-1}$ and soybean $64.7 \mathrm{~kg} \mathrm{ha}^{-1} \mathrm{~N}$ from the atmosphere, while red clover intercropped with spring barley produced $65.4-82.7 \mathrm{~kg} \mathrm{ha}^{-1} \mathrm{~N}$ yearly.

2. Most of the total nitrogen $(\mathrm{N})$ accumulated by pea and soybean plants, $69 \%$ and $80 \%$ respectively, was removed with grain yield, while comparable percentages of $\mathrm{N}(59-68 \%)$ were left by the residues of red clover and spring barley mixture. Therefore, the greatest effect on subsequently grown spring wheat was exerted by the mixture of spring barley and red clover (yield increase $354-1414 \mathrm{~kg} \mathrm{ha}^{-1}$ compared with sole spring barley).

3. The residual effect of soybean on subsequent wheat crops was greater than that of pea. Efficiently nodulated soybean produced positive $+20.6 \mathrm{~kg} \mathrm{ha}^{-1}$ net $\mathrm{N}$ balance and increased the yield of spring wheat by $920 \mathrm{~kg} \mathrm{ha}^{-1}$ Pea resulted in the negative net $\mathrm{N}$ balance but managed to increase the yield of spring wheat by $534 \mathrm{~kg} \mathrm{ha}^{-1}$ through other soil and ecosystem processes not related to $\mathrm{N}$.

\section{Acknowledgements}

This research was partially funded by the longterm LAMMC program "Biopotential and quality of plants for multifunctional use". We also acknowledge the support provided by all technical personnel for fieldwork and laboratory analyses.

Received 14062019

Accepted 26082019

\section{References}

1. Albareda M., Rodriguez-Navarro D. N., Temprano F. J. 2009. Soybean inoculation: dose, $\mathrm{N}$ fertilizer supplementation and rhizobia persistence in soil. Field Crops Research, 113: 352-356. https://doi.org/10.1016/j.fcr.2009.05.013

2. Angus J. F., Kirkegaard J. A., Hunt J. R., Ryan M. H. Ohlander L., Peoples M. B. 2015. Break crops and rotations for wheat. Crop and Pasture Science, 66: 523-552. https://doi.org/10.1071/CP14252

3. Batista M. B. Dixon R. 2019. Manipulating nitrogen regulation in diazotrophic bacteria for agronomic benefit Biochemical Society Transactions, 47 (2): 1-12. https://doi.org/10.1042/BST20180342

4. Bujak K., Frant M 2009. Influence of mixtures of herbicides on yielding and weed infestation of five cultivars of soybean. Acta Agrophysics, 13 (3): 601-613.

5. Catroux G., Hartmann A., Revellin C. 2001. Trends in rhizobial inoculant production and use. Plant and Soil, 230: 21-30. https://doi.org/10.1023/A:1004777115628

6. Cerezini P., Kuwano B. H., dos Santos M. B., Terassi F., Hungria M., Nogueira M. A. 2016. Strategies to promote early nodulation in soybean under drought. Field Crops Research, 196: 160-167. https://doi.org/10.1016/j.fcr.2016.06.017

7. Chalk P. M., Alves B. J. R., Boddey R. M., Urquiaga S. 2010. Integrated effects of abiotic stresses on inoculant performance, legume growth and symbiotic dependence estimated by ${ }^{15} \mathrm{~N}$ dilution. Plant and Soil, 328: $1-16$. https://doi.org/10.1007/s11104-009-0187-7

8. De Notaris Ch., Rasmussen J., Sørensen P., Melander B., Olesen J. E. 2019. Manipulating cover crop growth by adjusting sowing time and cereal inter-row spacing to enhance residual nitrogen effects. Field Crops Research, 234: 15-25. https://doi.org/10.1016/j.fcr.2019.02.008
9. de Visser C. L. M., Schreuder R., Stoddard F. 2014. The EU's dependency on soya bean import for the animal feed industry and potential for EU produced alternatives. Oilseeds and fats Crops and Lipids, 21 (4): 1-8. https://doi.org/10.1051/ocl/2014021

10. Deaker R., Roughley R. J., Kennedy I. R. 2004. Legume seed inoculation technology - a review. Soil Biology and Biochemistry, 36: 1275-1288. https://doi.org/10.1016/j.soilbio.2004.04.009

11. Ehrmann J., Ritz K. 2014. Plant: soil interactions in temperate multi-cropping production systems. Plant and Soil, 376: 1-29. https://doi.org/10.1007/s11104-013-1921-8

12. Espinoza S., Ovalle C., Zagal E., Matus J., Tay J., Peoples M. B., del Pozo A. 2012. Contribution of legumes to wheat productivity in Mediterranean environments of central Chile. Field Crops Research, 133: 150-159. https://doi.org/10.1016/j.fcr.2012.03.006

13. Feiziene D., Feiza V., Povilaitis V., Putramentaite A., Janusauskaite D., Seibutis V., Slepetys J. 2016. Soil sustainability changes in organic crop rotations with diverse crop species and the share of legumes. Acta Agriculturae Scandinavica, Section B: Soil and Plant Science, 66 (1): 36-51. https://doi.org/10.1080/09064710.2015.1063683

14. Fogelberg F., Fogelberg C. L. 2013. Swedish soya bean cropping - introduction of a hot crop to a cool climate. Legume Perspectives, $1: 31-32$.

15. Foley J. A., Ramankutty N., Brauman K. A. et al. 2011. Solutions for a cultivated planet. Nature, 478: 337-342. https://doi.org/10.1038/nature10452

16. Grant A., O'Donovan J. T., Blackshaw R. E. et al. 2016. Residual effects of preceding crops and nitrogen fertilizer on yield and crop and soil $\mathrm{N}$ dynamics of spring wheat and canola in varying environments on the Canadian prairies. Field Crops Research, 192: 86-102. https://doi.org/10.1016/j.fcr.2016.04.019

17. Herridge D. F., Danso S. K. A. 1995. Enhancing crop legume $\mathrm{N}$ fixation through selection and breeding. Plant and Soil, 174: 51-82. https://doi.org/10.1007/978-94-011-0053-3_3

18. Herridge D., Rose I. 2000. Breeding for enhanced nitrogen fixation in crop legumes. Field Crop Research, 65: 229248. https://doi.org/10.1016/S0378-4290(99)00089-1

19. Iannetta P. P., Young M., Bachinger J. et al. 2016. A comparative nitrogen balance and productivity analysis of legume and non-legume supported cropping systems: the potential role of biological nitrogen fixation. Frontiers in Plant Science, 7: 1-13. https://doi.org/10.3389/fpls.2016.01700

20. Ingver A., Tamm U., Tamm I., Tamm S., Tupits I., Bender A., Koppel R., Narits L., Koppel M. 2019. Leguminous pre-crops improved quality of organic winter and spring cereals. Biological Agriculture and Horticulture, 35 (1): 46-60. https://doi.org/10.1080/01448765.2018.1509728

21. Janušauskaitė D., Arlauskienė A., Maikštènienė S. 2013. Soil mineral nitrogen and microbial parameters as influenced by catch crops and straw management. Zemdirbyste-Agriculture, 100 (1): 9-18. https://doi.org/10.13080/z-a.2013.100.002

22. Jensen E. S. 1996. Grain yield, symbiotic $\mathrm{N}$ fixation and interspecific competition for inorganic $\mathrm{N}$ in pea-barley intercrops. Plant and Soil, 182: 25-38. https://doi.org/10.1007/BF00010992

23. Kumar K., Goh K. M. 2000. Biological nitrogen fixation, accumulation of soil nitrogen and nitrogen balance for white clover (Trifolium repens L.) and field pea (Pisum sativum L.) grown for seed. Field Crops Research, 68: 49-59. https://doi.org/10.1016/S0378-4290(00)00109-X

24. Liu X., Jin J., Wang G., Herbert S. J. 2008. Soybean yield physiology and development of high-yielding practices in Northeast China. Field Crops Research, 105: 157-171. https://doi.org/10.1016/j.fcr.2007.09.003

25. Luce M. S., Grant C. A., Zebarth B. J. et al. 2015. Legumes can reduce economic optimum nitrogen rates and increaseyields in a wheat-canola cropping sequence in western Canada. Field Crops Research, 179: 12-25. https://doi.org/10.1016/j.fcr.2015.04.003

26. Migliorini P., Moschini V., Tittarelli F., Ciacciac C., Benedettelli S., Vazzana C., Canalic S. 2014. Agronomic performance, carbon storage and nitrogen utilisation of long-term organic and conventional stockless arable systems in Mediterranean area. European Journal of Agronomy, 52: 138-145. https://doi.org/10.1016/j.eja.2013.09.017

27. Nemecek T., von Richthofen J.-S., Dubois G., Casta P. Charles R., Pahl H. 2008. Environmental impacts of introducing grain legumes into European crop rotations. European Journal of Agronomy, 28: 380-393. https://doi.org/10.1016/j.eja.2007.11.004

28. Nielsen D. C. 2011. Forage soybean yield and quality response to water use. Field Crops Research 124: 400-407. https://doi.org/10.1016/j.fcr.2011.07.007 
29. Pandey A., Li F., Askegaard M., Olesen J. E. 2017. Biological nitrogen fixation in three long-term organic and conventional arable crop rotation experiments in Denmark. European Journal of Agronomy, 90: 87-95. https://doi.org/10.1016/j.eja.2017.07.009

30. Peoples M. B., Gault R. R., Lean B., Sykes J. D. Brockwell J. 1995. Nitrogen fixation by soybean in commercial irrigated crops in central and southern New South Wales. Soil Biology and Biochemistry, 27: 553-561. https://doi.org/10.1016/0038-0717(95)98631-W

31. Peoples M. B., Brockwell J., Herridge D. F. et al. 2009. The contributions of nitrogen-fixing crop legumes to the productivity of agricultural systems. Symbiosis, 48: 1-17. https://doi.org/10.1007/BF03179980

32. Preissel S., Reckling M., Schläfke N., Zander P. 2015. Magnitude and farm-economic value of grain legume precrop benefits in Europe: a review. Field Crops Research, 175: 64-79. https://doi.org/10.1016/i.fcr.2015.01.012

33. Räberg T., Carlsson G., Jensen E. S. 2018. Nitrogen balance in a stockless organic cropping system with different strategies for internal $\mathrm{N}$ cycling via residual biomass. Nutrient Cycling of Agroecosystems, 112: 165178. https://doi.org/10.1007/s10705-018-9935-5

34. Ray K. D., Ramankutty N., Mueller N. D., West P. C. Foley J. A. 2012. Recent patterns of crop yield growth and stagnation. Nature Communications, 3: 1293. https://doi.org/10.1038/ncomms2296

35. Reckling M., Hecker J.-M., Bergvist G., Watson Ch. A., Zander P., Schläfke N., Stoddard F. L., Eory V., Topp C. F. E, Maire J., Bachinger J. 2016. A cropping system assessment framework - evaluating effects of introducing legumes into crop rotations. European Journal of Agronomy, 76: 186197. https://doi.org/10.1016/j.eja.2015.11.005

36. Rochester M. J., Peoples M. B., Hulugalle N. R., Gault R. R., Constable G. A. 2001. Using legumes to enhance nitrogen fertility and improve soil condition in cotton cropping system. Field Crop Research, 70: 27-41.

https://doi.org/10.1016/S0378-4290(00)00151-9
37. Seufert V., Ramankutty N., Foley J. A. 2012. Comparing the yields of organic and conventional agriculture. Nature, 485: 229-232. https://doi.org/10.1038/nature11069

38. Stoddard F. L. 2013. Agronomic case studies in legume futures. Legume Futures Report 1.2. University of Helsinki, Finland, $82 \mathrm{p}$

39. Šarūnaitė L., Kadžiulienė Z., Deveikytė I., Kadžiulis L. 2013. Effect of legume biological nitrogen on cereals grain yield and soil nitrogen budget in double-cropping system. Journal of Food, Agriculture and Environment, 11: 528-533.

40. Tiemann L. K., Grandy A. S., Atkinson E. E., MarinSpiotta E., McDaniel M. D. 2015. Crop rotational diversity enhances belowground communities and functions in an agroecosystem. Ecology Letters, 18: 761-771.

https://doi.org/10.1111/ele.12453

41. Unkovich M. J., Pate J. S. 2000. An appraisal of recent field measurements of symbiotic $\mathrm{N}_{2}$ fixation by annual legumes. Field Crops Research, 65: 211-228.

https://doi.org/10.1016/S0378-4290(99)00088-X

42. Unkovich M. J., Baldock J., Peoples M. B. 2010. Prospects and problems of simple linear models for estimating symbiotic $\mathrm{N}_{2}$ fixation by crop and pasture legumes. Plant and Soil, 329: 75-89. https://doi.org/10.1007/s11104-009-0136-5

43. Watson C. A., Reckling M., Preissel S., Bachinger J., Bergkvist G., Kuhlman T., Lindström K., Nemecek T., Topp C. F. E., Vanhatalo A., Zander P., Murphy-Bokern D. Stoddard F. L. 2017. Grain legume production and use in European agricultural systems. Advances in Agronomy, 144: 236-303. https://doi.org/10.1016/bs.agron.2017.03.003

44. Wenda-Piesik A., Kazek M. 2016. Productivity of early maturing cultivars of soybeans (Glycine max L. Merr.) in North-Western Poland. 14 ${ }^{\text {th }}$ ESA Congress, Edinburgh, Scotland. Abstracts book, p. 25-26.

45. WRB. 2014. World reference base for soil resources. World Soil Resources Reports No. 106. FAO, p. 187-189.

46. Zimmer S., Messmer M., Haase T., Piepho H., Mindermann A., Schulz H., Habekub A., Ordon F., Wilbois K., Heb J. 2016. Effects of soybean variety and Bradyrhizobium strains on yield, protein content and biological nitrogen fixation under cool growing conditions in Germany. European Journal of Agronomy, 7: 38-46. https://doi.org/10.1016/j.eja.2015.09.008

ISSN 1392-3196 / e-ISSN 2335-8947

Zemdirbyste-Agriculture, vol. 106, No. 4 (2019), p. 321-328

DOI 10.13080/z-a.2019.106.041

\title{
Gauruotosios sojos ijjungimas ị ekologinę sẻjomainą nemoralinèje zonoje: įtaka po jų augintų vasarinių kviečių produktyvumui
}

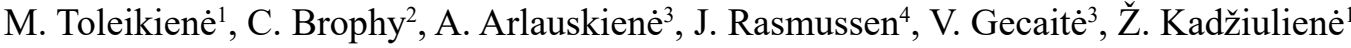 \\ ${ }^{1}$ Lietuvos agrarinių ir miškų mokslų centro Žemdirbystès institutas \\ ${ }^{2}$ Meinuto universiteto Matematikos ir statistikos skyrius, Airija \\ ${ }^{3}$ Lietuvos agrarinių ir miškų mokslų centro Joniškèlio bandymų stotis \\ ${ }^{4}$ Arhuso universiteto Agroekologijos, klimato ir vandens skyrius, Danija
}

\section{Santrauka}

Ekologinès sejjomainos tvarumas dažnai priklauso nuo pupiniu augalu priešsėliu liekamojo efekto. Tačiau pupiniu augalų indèlis labai skiriasi priklausomai nuo jų rūšies, taip pat vietinio dirvožemio ir klimato sąlygų. Tyrimo tikslas - palyginti tradiciniu grūdiniu ir žoliniu pupiniu augalu itaka po ju augintu kviečiu produktyvumui su gauruotosios sojos (Glycine max (L.) Merr.), kuri nèra plačiai paplitusi Europos $55^{\circ}$ platumos klimato sąlygomis. Trejų metų trukmès sejjomaina buvo tirta auginant keturis priešsėlius: vasarinius miežius, vasarinius miežius su raudonujų dobilų isėliu, sėjamuosius žirnius ir gauruotąsias sojas. Buvo tirta priešsėlio itaka vėliau augintu vasariniu kviečiu derliui, jo kokybei ir cheminei sudèčiai. Nustatytas azoto $(\mathrm{N})$ kiekis grūduose ir šiauduose, mineralinio azoto kiekis dirvožemyje, taip pat apskaičiuotas C:N santykis ir suminis N balansas. Sejomaina buvo kartota du kartus. Eksperimento rezultatai atskleidè, kad grūdiniai pupiniai augalai žirniai ir sojos sukaupė nepakankamą kiekị biomasès ir fiksuoto azoto, $\mathrm{kad}$ būtu išlaikyta stabili teigiama augaliniu liekanu itaka abiejuose sëjomainos rotacijos pakartojimuose. Tik esant palankioms sąlygoms žirniai iš atmosferos sukaupe $66,1 \mathrm{~kg} \mathrm{ha}^{-1} \mathrm{~N}$, sojos $-64,7 \mathrm{~kg} \mathrm{ha}^{-1} \mathrm{~N}$, o raudonieji dobilai, sèti su vasariniais miežiais, kasmet sukaupe $65,4-82,7 \mathrm{~kg} \mathrm{ha}^{-1} \mathrm{~N}$. Zirniai ir sojos 69 ir $80 \%$ viso azoto sukaupè grūduose, o raudonųjų dobilų ir vasarinių miežių mišinys 59-68 \% - augalinèse liekanose. Todèl vèliau augintiems vasariniams kviečiams didžiausią įtaką padarè vasarinių miežių ir raudonujų dobilų mišinys - gautas $354-1414 \mathrm{~kg} \mathrm{ha}^{-1}$ derliaus priedas. Palyginus grūdinius pupinius augalus, tik efektyviai gumbelius formuojančios sojos turèjo teigiamą suminị $\mathrm{N}$ balansą $\left(+20,6 \mathrm{~kg} \mathrm{ha}^{-1}\right)$ ir vasarinių kviečių derlingumą padidino $920 \mathrm{~kg} \mathrm{ha}^{-1}$. Žirniai turèjo neigiamą suminị $\mathrm{N}$ balansą ir vasariniu kviečiu derlingumą padidino $534 \mathrm{~kg} \mathrm{ha}^{-1}$. Dirvožemyje mineralinio azoto kiekis padidèjo auginant visus pupinių augalų priešsėlius, tačiau tik antraisiais sejjomainos metais.

Reikšminiai žodžiai: azotas, priešsėlis, raudonieji dobilai, žirniai. 